\title{
QUALITY OF PHYSALIS (PHYSALIS PUBESCENS L.) JUICE PACKAGED IN GLASS BOTTLES AND FLEXIBLE LAMINATED PACKS DURING STORAGE AT $5^{\circ} \mathrm{C}$
}

\author{
El-Sheikha $A F^{1,2}$, Ribeyre $\mathrm{F}^{2}$, Larroque $\mathrm{M}^{3}$, Reynes $\mathrm{M}^{2}$ and $\mathrm{D}$ Montet ${ }^{2}$
}

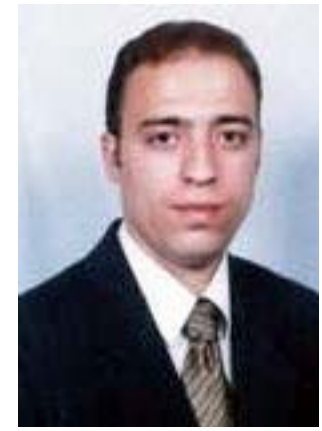

El-Sheikha Aly

*Corresponding author email: elsheikha_aly@yahoo.com

${ }^{1}$ Minufiya University, Faculty of Agriculture, Department of Food Science and Technology, 32511 Shibin El Kom, Minufiya Government, Egypt.

${ }^{2}$ CIRAD, UMR Qualisud, TA B-95/16, 34398 Montpellier Cedex 5, France.

${ }^{3}$ Faculty of Pharmacy, UMR Qualisud, 15 Av. Charles Flahault BP 14491, 34393 Montpellier Cedex 5, France. 


\section{ABSTRACT}

Husk tomato (Physalis pubescens L.) is one of the important 100 species in the Physalis genus of the Solanaceae family. Among unexploited tropical fruits, Physalis is a very promising fruit. Physalis is included in the priority list of many governments' horticulture and fruit export plans. It is relatively unknown in importing markets and remains an exotic fruit. The important step toward developing Physalis as a commercial crop was maximizing its technological applications. The objective of our study was to prepare a new processed pasteurized Physalis juice and to study the effects of storage and packaging on its nutritional properties. The pulp was yellowish or orange with a yield of $64 \%$. The fresh juice had a light sweet and acidic taste $(\mathrm{pH}$ 3.5). The titratable acidity was $1.43 \%$, polyphenols $76.6 \mathrm{mg} / 100 \mathrm{~mL}$ and vitamin $\mathrm{C}$ $38.8 \mathrm{mg} / 100 \mathrm{~mL}$. Physalis juice was rich in carotenoids $(70 \mu \mathrm{g} / \mathrm{mL})$. The nutritional and bio-physical characteristics of Physalis juice packaged in glass bottles and flexible laminated packs during storage under refrigeration $\left(5 \pm 1^{\circ} \mathrm{C}, 85-90 \% \mathrm{RH}\right)$ for 6 months were studied. Carotenoids, polyphenolic substances and ascorbic acid contents were gradually reduced throughout cold storage, where this reduction was more pronounced in juice packaged in flexible laminated packs. A slight increase in total acidity was observed with cold storage prolongation, especially in juice packaged in flexible laminated packs. Significant differences in color were found between the same juice packaged either in glass bottles or in flexible laminated packs, where the juice color was darker in flexible laminated packs. It could be noticed that, there was no migration of $\mathrm{Na}$ ions from glass bottles to processed juice formulas during the cold storage period. In flexible laminated packs, a slight increase of $\mathrm{Al}$ ions throughout the cold storage period but not exceeding the safety limit of Al daily intake (3.5mg/day). It was concluded that Physalis juice packaged in glass bottles had higher storage stability than that packaged in flexible laminated packs.

Key words: Physalis pubescens, Juice, Storage stability, Packaging 


\section{INTRODUCTION}

Husk tomato fruit belongs to the Solanaceae family. It is native to tropical and subtropical American regions. Physalis fruit and juice are nutritious, containing particularly high levels of niacin, carotenoids and minerals [1]. A single plant may yield up to $0.5 \mathrm{~kg}$ fruits and carefully tended plants can provide $20-33$ tons/hectare [2]. The fruit is a berry $(1.25-2 \mathrm{~cm}$, wide), with smooth, waxy, orange-yellowish kernels. The part of the Physalis that can be used is composed of husk (6\%) and berry (94\%). They are protected by papery husks with many minute seeds in a juicy pulp which is sweet and tangy resembling Chinese lanterns [3]. Physalis already carries prestige in some international markets. Europeans, for example, often pay premium prices to dip the berries in chocolate or decorate cakes and pies. In addition to having a future as fresh fruits, the exotic fruit can be enjoyed in many ways as an interesting ingredient in salads, cooked dishes, dessert and jam and natural snacks [4]. Fruits are long-lasting, can be stored in a sealed container and can be frozen or kept in a dry atmosphere for several months [5].

Physalis is included in the priority list of many governments' horticulture and fruit export plans. It is relatively unknown in importing markets and remains an exotic fruit [6]. It is exported from several countries including Colombia and African countries; Egypt, Zimbabwe and South Africa, but Colombia stands out as one of the largest producers, consumers and exporters [7]. In that country, Physalis occupies second position in the priority list of 15 exportable fruits. Exports of this crop in 2004 were worth 14 million USD [8]. In Egypt, Physalis has been known for a long time. Recently, the economic importance of Physalis is rising due to high acceptance for local consumption, achieving a great success in Arabic and European markets [6].

The quality and shelf life of fruit juice depend upon a range of internal parameters related to the product and several external factors, packaging being one of them [9]. Intermediate Technology Development Group [10] reported that glass containers are inert and do not react with/or migrate into food products. However, Pankow [11] believed that sodium migration is involved in the delaminating mechanism of soda lime glass. Sodium plays a pivotal role in enzyme operation and muscle contraction. It is important for osmo-regulation and fluid maintenance of the human body. Other health implications of sodium include heart performance, nervous system and glucose absorption. Though sodium is an essential nutrient in the balanced diet, it also causes stomach cancer and hypertension [12]. Those who are suffering from kidney problems and edema should strictly restrict the consumption of sodium in their daily diet [12].

Over the last few years, there has been concern about aluminum exposure resulting from leaching of aluminum from cookware and beverage packs [13]. Certain aluminum compounds have been found to be an important component of the neurological damage seen with Alzheimer's disease. Much research over the last decade has focused on the role of aluminum in the development of this disease [14].

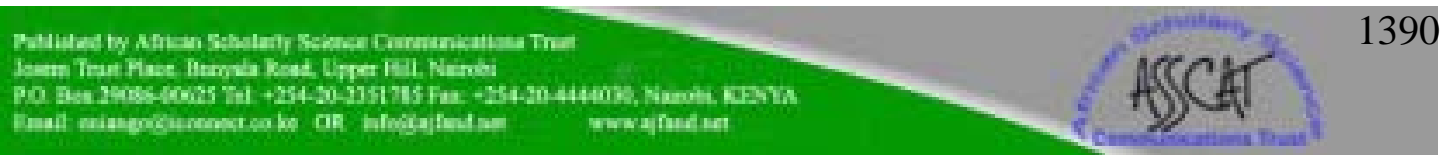


Additionally, no attention has been paid to the utilization of Physalis fruits in food industries, and there is little available data in the literature regarding its nutritional properties and industrial utilization. This work is for the first time providing useful information for storage properties and industrial applications of Physalis. The purpose of this study was to evaluate the nutritional and bio-physical characteristics of Physalis juice packaged in glass bottles and flexible laminated packs during storage for 6 months under refrigeration $\left(5 \pm 1{ }^{\circ} \mathrm{C}, 85-90 \% \mathrm{RH}\right)$. With the aim of developing Physalis as a commercial crop, the data obtained will be important as an indicator of the potential nutraceutical and economical utility of Physalis as an unexploited tropical source of fruit juices.

\section{MATERIALS AND METHODS}

\section{Biological material}

Ripe Physalis pubescens L. fruits were obtained from local growers at Arab ElRawshda village, Toukh region, Qalyoubia Governorate located in the north of Egypt during the mid-May 2004 season. Intact fruits were carefully selected according to the degree of ripeness measured by fruit color (brilliant orange). The fresh fruits were analyzed immediately after harvesting.

\section{Packaging material}

Colorless glass bottles with capacity of $240 \mathrm{~g}$ were obtained from El-Nasr Glass Industry Co., Cairo, Egypt. Flexible laminated packs consisted of three laminars: polyester, aluminum foil and high density polyethylene (PES/FOIL/HDPE). The specifications of flexible laminated films are given in Table 1. Flexible laminated packs were purchased from Egyptian Canning Co., Aga, Dakahlia Governorate, Egypt.

\section{Extraction and preparation of Physalis fruit juice}

Physalis fruits were dehusked manually, sorted to select the ripe and intact ones and graded depending mainly on their color, then washed. Then, the fruits were pulped using a fruit pulper (Braun, Model 2001, Germany) for juice extraction. Juice was filtrated in cheesecloth to separate seeds and skins and sucrose was added up to $17 \%$ of Total Soluble Solids "TSS"; Physalis juice was pasteurized at $90^{\circ} \mathrm{C}$ for $3 \mathrm{~min}$. After heat treatment, $0.3 \%$ citric acid and $0.1 \%$ sodium benzoate were added to prevent the growth of undesirable microorganisms such as lactic acid bacteria and fermentation yeast. The pasteurized juice was packaged by hot filling in glass bottles and capped tightly then cooled suddenly in a cold water bath. Processed juices were stored in refrigerator at $5 \pm 1{ }^{\circ} \mathrm{C}, 85-90 \% \mathrm{RH}$ for 6 months.

\section{Determination of major nutrient components of Physalis juice}

Crude protein was determined by micro Kjeldahl method and calculated by using the conversion factor $(\% \mathrm{~N} \times 6.25)$ according to the method mentioned in AOAC [15]. The $\mathrm{pH}$ value of the prepared samples were measured at $25^{\circ} \mathrm{C}$ by using a digital $\mathrm{pH}$ meter (Jenway, Model 3020, England) according to the method described in AOAC [15]. The total carotenoid content was determined in the $80 \%$ acetone extract and 
measured spectrophotometrically at $440 \mathrm{~nm}$ as $\left(\mu \mathrm{g} \cdot \mathrm{mL}^{-1}\right)$ according to the method of AOAC [15]. Reducing sugars were determined (as glucose) colorimetrically at 490 $\mathrm{nm}$ as reported by Dubois et al. [16]. Total acidity was titrated with $0.1 \mathrm{~N} \mathrm{NaOH}$ using phenolphthalein as an indicator and was expressed as anhydrous citric acid/100g of sample. Ascorbic acid was estimated by the colorimetric method of Folin-Ciocalteu at $760 \mathrm{~nm}$ [17]. Total polyphenolic substances were measured (as tannic acid) colorimetrically at $640 \mathrm{~nm}$ by the Folin-Ciocalteu method [18].

\section{Statistical analysis}

The data of the storage study were subjected to two way ANOVA analysis (Variance Analysis), significance was set at $\mathrm{p}<0.05$. Least significant difference (LSD) as multivariate test enabled to set up average homogenized groups as reported by Dagnelie [19]. The analysis was performed using XLSTAT 2007.2 (Statistical Software for MS Excel, version 2007, Addinsoft, USA).

\section{RESULTS}

\section{Nutritional evaluation of fresh Physalis juice}

Physalis pulp was yellowish or orange with a yield of 64\%. The fresh juice had a light sweet and acidic taste $(\mathrm{pH} 3.5)$. The titratable acidity was $1.43 \%$. Carotenoid content was $70 \mu \mathrm{g} / \mathrm{mL}$. The fresh juice contained a considerable amount of polyphenols $(76.6 \mathrm{mg} / 100 \mathrm{~mL})$ as tannic acid; this amount covered approximately $8 \%$ of Dietary Reference Intakes "DRIs" of polyphenols (1g/day) [20, 21]. Ascorbic acid was $38.8 \mathrm{mg} / 100 \mathrm{~mL}$ whereas this amount covered approximately $43-52 \%$ of DRIs of ascorbic acid (75-90g/day) [20, 21]. On the other hand, fresh Physalis juice was poor in protein $(1.02 \% \mathrm{ww})$ [21] whereas this amount covered approximately $1.8-2.3 \%$ of DRIs of proteins.

\section{Storage and packaging effects on physico-chemical characteristics Changes in $\mathrm{pH}$ and total titratable acidity}

Fig. 1 shows the decrease of $\mathrm{pH}$-values $(\mathrm{p}<0.05)$ of processed Physalis juice during the first four months and stable in the fifth month, then increase in the sixth month of the storage time under refrigeration at $5^{\circ} \mathrm{C}$ in two packaging materials. The $\mathrm{pH}$ decreased conversely to total titratable acidity (Fig. 2). Significant differences $(\mathrm{p}<0.05)$ of $\mathrm{pH}$-values and total titratable acidity were found between the two studied packaging materials (Table 2$)$. Moreover, there were significant variances $(p<0.05)$ in $\mathrm{pH}$-values and total titratable acidity due to the interaction between the storage time under refrigeration conditions and the packaging materials. 


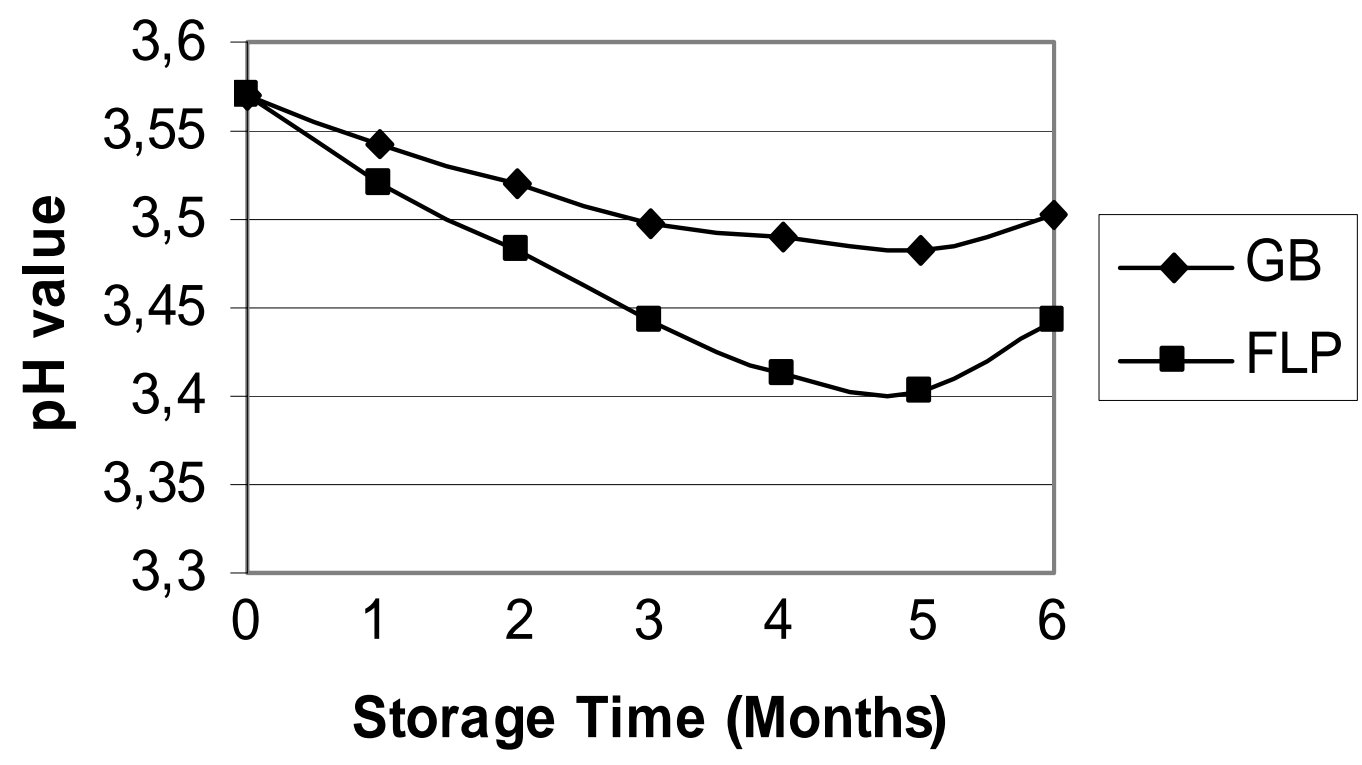

Figure 1: $\mathrm{pH}$-value of refrigerated $\left(5 \pm 1^{\circ} \mathrm{C}, 85-90 \% \mathrm{RH}\right)$ Physalis juice stored in glass bottles (GB) and flexible laminated packs (FLP)

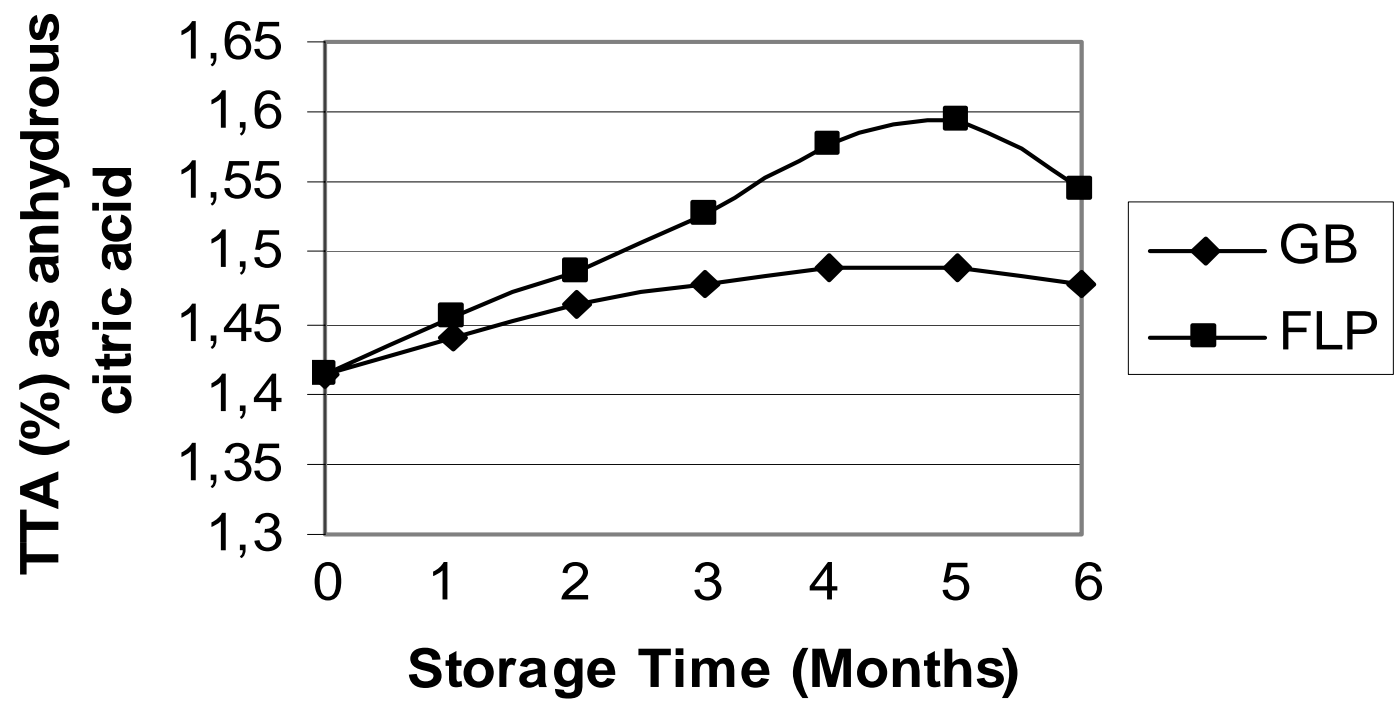

Figure 2: Total titratable acidity (TTA \%) as anhydrous citric acid of refrigerated $\left(5 \pm 1^{\circ} \mathrm{C}, 85-90 \% \mathrm{RH}\right)$ Physalis juice stored in glass bottles (GB) and flexible laminated packs (FLP) 


\section{Changes in color index (as O.D. at $420 \mathrm{~nm}$ )}

The color index of refrigerated Physalis juice throughout 6 months of storage increased significantly $(\mathrm{p}<0.05)$ (Fig. 3). Table 2 shows significant variation $(\mathrm{p}<0.05)$ in juice color index measurements due to the packaging materials and their interactions.

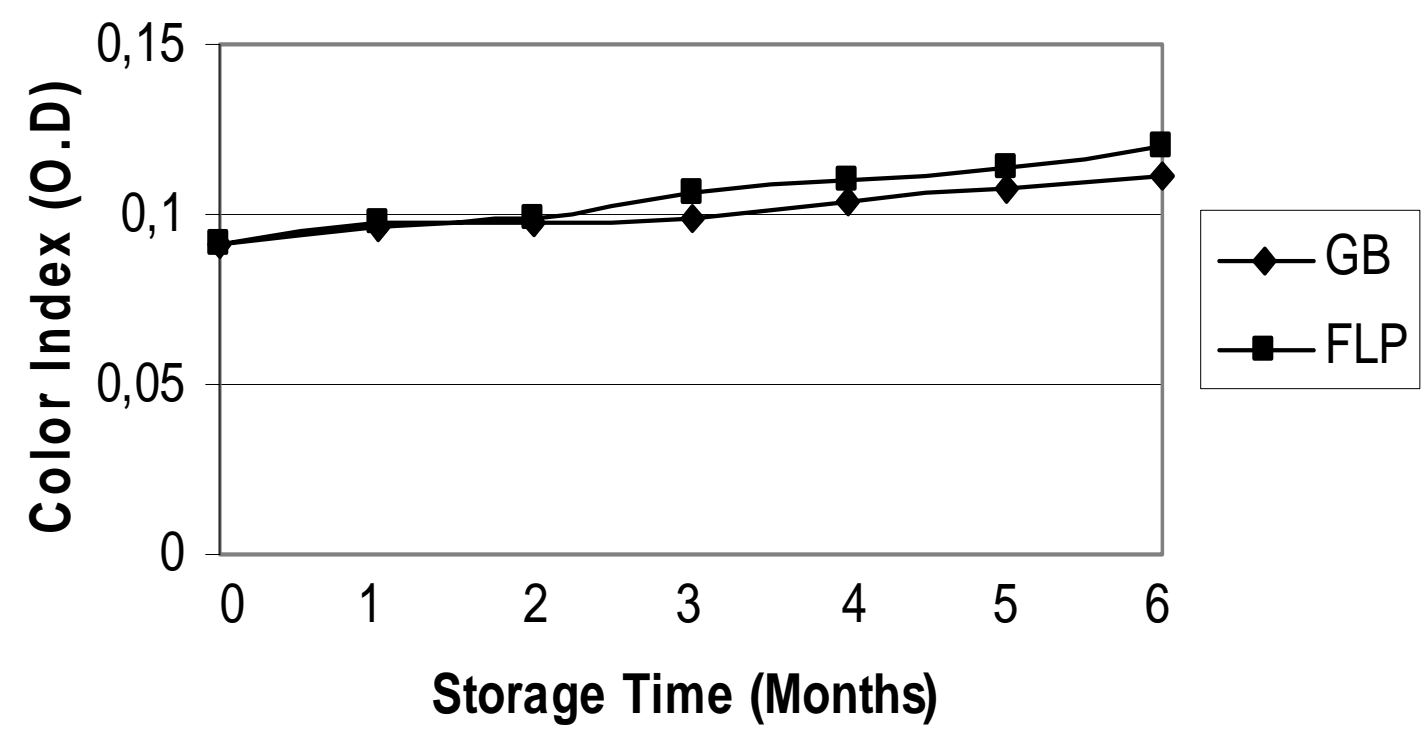

Figure 3: Color index as $(O . D$ at $420 \mathrm{~nm})$ of refrigerated $\left(5 \pm 1^{\circ} \mathrm{C}, 85-90 \% \mathrm{RH}\right)$ Physalis juice stored in glass bottles (GB) and flexible laminated packs (FLP)

\section{Storage and packaging effects on chemical composition}

\section{Changes in reducing sugars}

Reducing sugars content increased from $39.5 \%(\mathrm{dw})$ at $\mathrm{T}_{0}$ to $45.5 \%(\mathrm{dw})$ after 5 months proportionally to the increase of the storage time under refrigeration but decreased in the_sixth month (Fig. 4). Significant differences $(p<0.05)$ could be clearly noticed for reducing sugars values during the storage period (Table 2). In addition, it could be clearly noticed that there were significant differences $(p<0.05)$ in reducing sugars values between packaging materials and the interactions between both factors studied. 


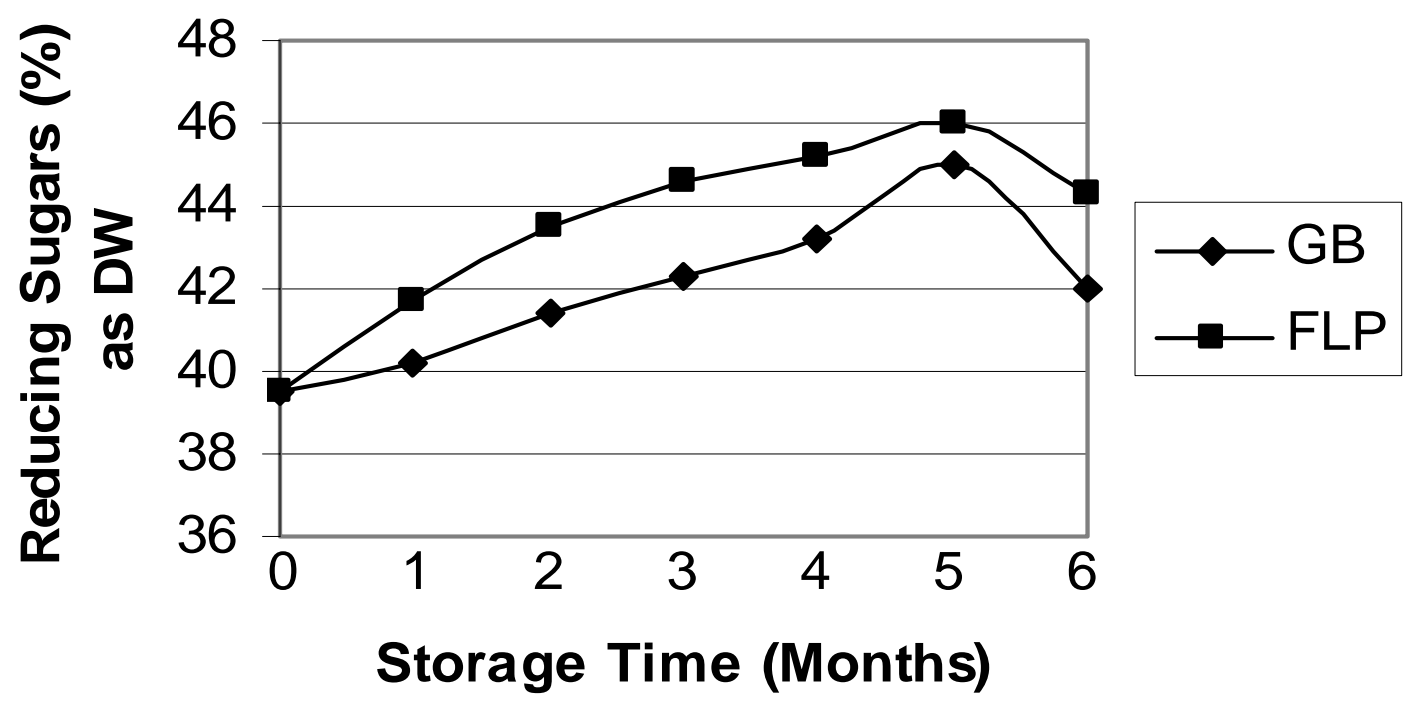

Figure 4: Reducing sugars content $(\%)$ of refrigerated $\left(5 \pm 1^{\circ} \mathrm{C}, 85-90 \% \mathrm{RH}\right)$ Physalis juice stored in glass bottles (GB) and flexible laminated packs (FLP)

\section{Changes in carotenoid content}

Carotenoid content decreased significantly $(\mathrm{p}<0.05)$ during the cold storage for 6 months (Fig. 5). Table 2 shows significant differences $(\mathrm{p}<0.05)$ in carotenoid content between the two different packaging materials which are used for packaging juice formulations. There were non-significant interactions $(\mathrm{p}<0.05)$ between the storage time under refrigeration conditions and the packaging materials.

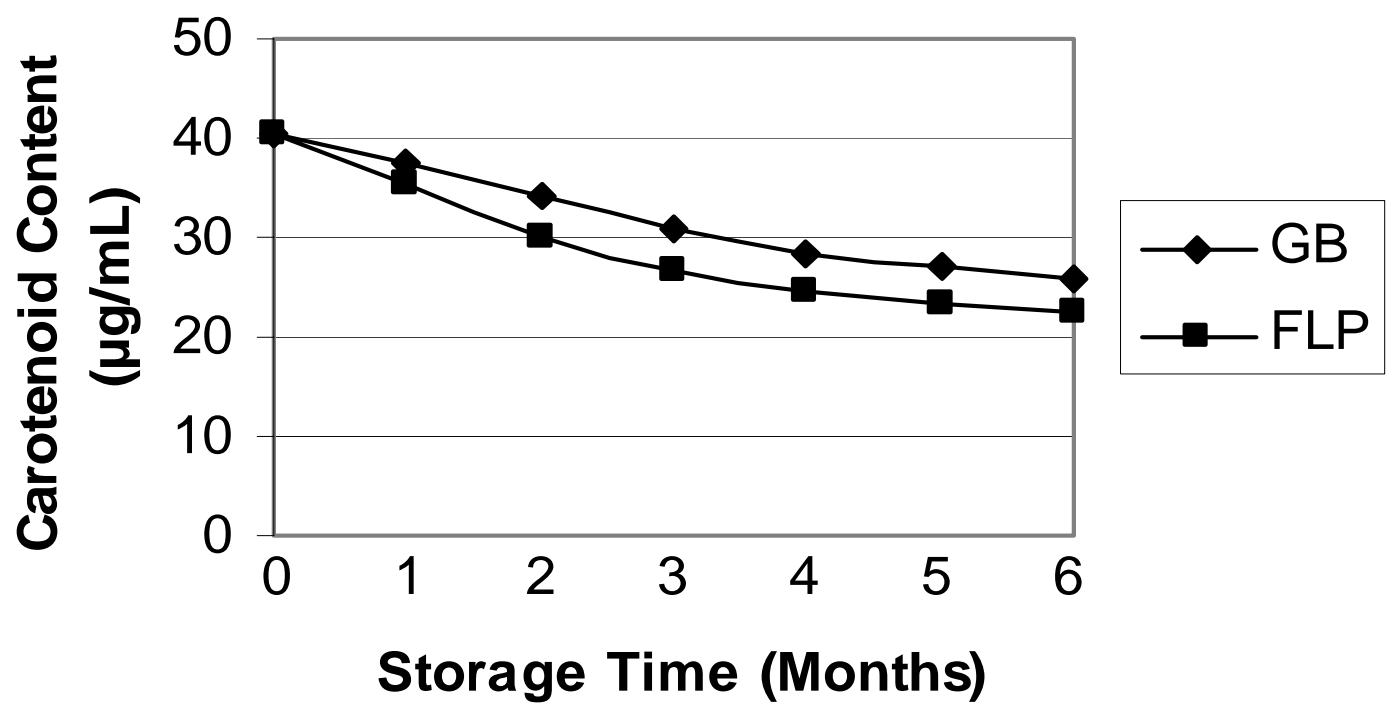

Figure 5: Carotenoid content $(\mu \mathrm{g} / \mathrm{mL})$ of refrigerated $\left(5 \pm 1^{\circ} \mathrm{C}, 85-90 \% \mathrm{RH}\right)$ Physalis juice stored in glass bottles (GB) and flexible laminated packs (FLP) 


\section{Changes in polyphenolic substances}

Fig. 6 and Table 2 reveal a large significant decrease $(\mathrm{p}<0.05)$ in polyphenolic content with storage time, regardless of the packaging materials and the interactions between the storage time and the packaging materials.

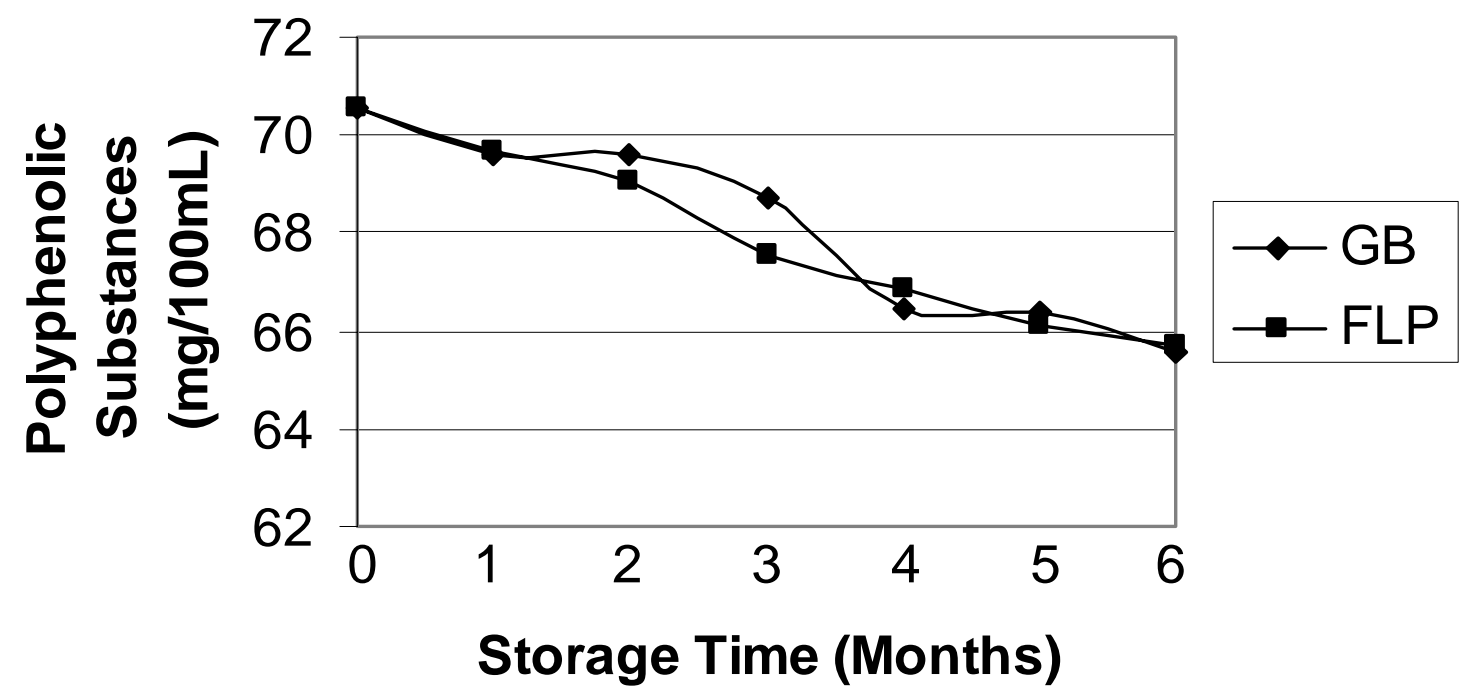

Figure 6: Polyphenolic substances $(\mathrm{mg} / 100 \mathrm{~mL})$ of refrigerated $\left(5 \pm 1^{\circ} \mathrm{C}, 85\right.$ 90\%RH) Physalis juice stored in glass bottles (GB) and flexible laminated packs (FLP)

\section{Changes in ascorbic acid content}

With the increase in cold storage time, ascorbic acid content decreased significantly $(\mathrm{p}<0.05)$ (Fig. 7). Data presented in Table 2 illustrated significant variation $(\mathrm{p}<0.05)$ in ascorbic acid content in processed juice due to packaging materials and interactions between the storage time under refrigeration conditions and the packaging materials. 


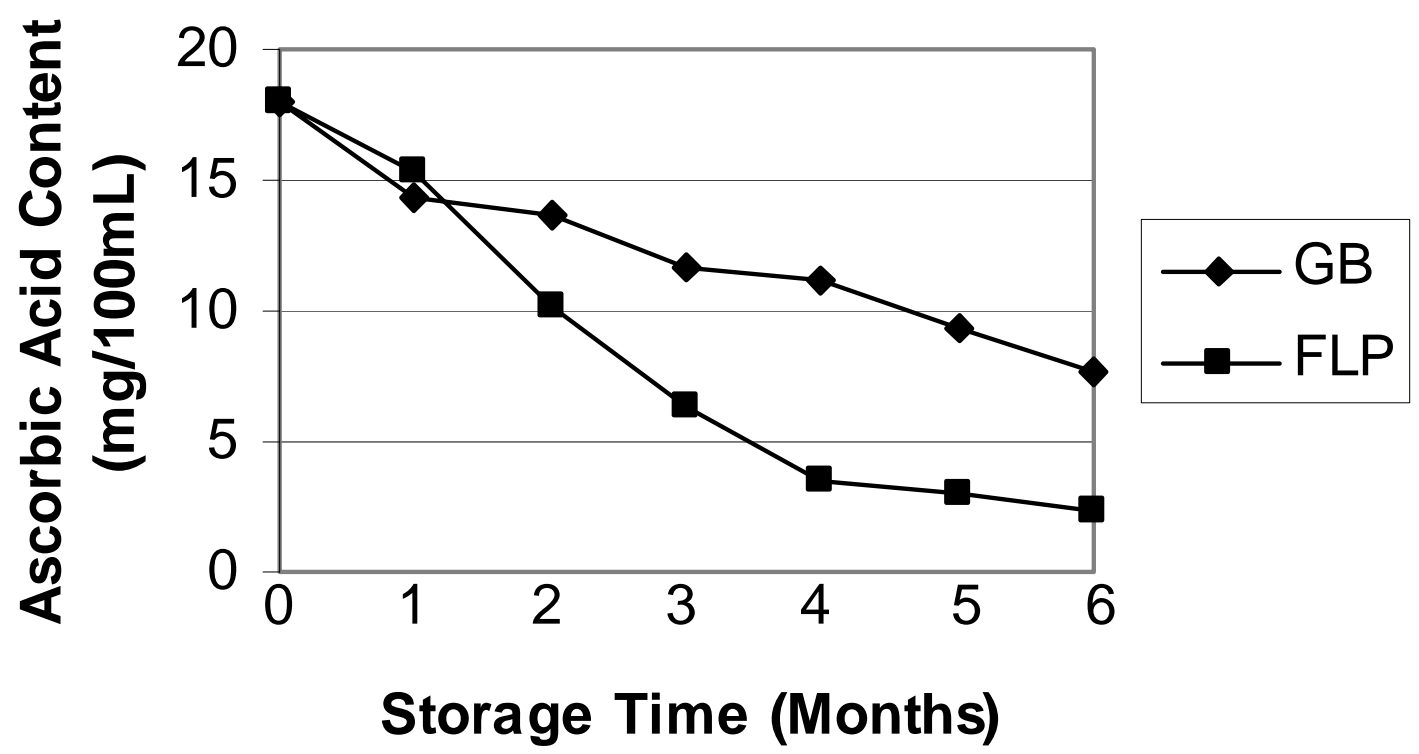

Figure 7: Ascorbic acid content $(\mathrm{mg} / 100 \mathrm{~mL})$ of refrigerated $\left(5 \pm 1^{\circ} \mathrm{C}, 85-90 \%\right.$ RH) Physalis juice stored in glass bottles (GB) and flexible laminated packs (FLP)

Migration of sodium and aluminum ions from packaging material to processed juice

The sodium ions concentration of processed juice ranged between 37.3 parts per million (ppm) to $37.5 \mathrm{ppm}$ during cold storage for 6 months. There was no migration of $\mathrm{Na}$ ions from glass bottles to the processed juice. Results given in Table 2 showed a significant increase $(\mathrm{p}<0.05)$ in aluminum ions of juice packaged in flexible laminated packs but not exceeding the safety limit of $\mathrm{Al}$ daily intake $(3.5 \mathrm{mg} /$ day).

\section{DISCUSSION}

\section{Nutritional evaluation of fresh Physalis juice}

The fresh juice had the same color as the fruit due to its very high carotenoid content $(70 \mu \mathrm{g} / \mathrm{mL})$, in comparison with cantaloupe juice which contains only $7.6 \mu \mathrm{g} / \mathrm{mL}$ [22], lemon juice $(0.3 \mu \mathrm{g} / \mathrm{mL})$, orange juice $(3.2 \mu \mathrm{g} / \mathrm{mL})$ and passion fruit juice $(4.4 \mu \mathrm{g} / \mathrm{mL})$ [23]. This type of color was also found for Physalis peruviana juice [24], Physalis ixocarpa juice [25] and Physalis pruinosa juice [26].

The $\mathrm{pH}$ of the fresh Physalis juice (3.6) was higher than citrus juices such as lime juice $(\mathrm{pH} 2.3)$ and lemon juice $(\mathrm{pH} 2.4)$ [27]. It was close to that of pineapple ( $\mathrm{pH} 3.2)$ [28] and orange juice $(\mathrm{pH}$ 3.6) [29], but lower than in fresh juice of Physalis peruviana ( $\mathrm{pH} 3.86$; Ramadan and Moersel [30]). The titratable acidity (1.43\%) was higher than that reported for Physalis peruviana (0.92\%) [30] and lemon juices $1.15 \%$ [27], but lower than that in two varieties of mango fruit juices (2.29\% and $4.11 \%)$ [31].

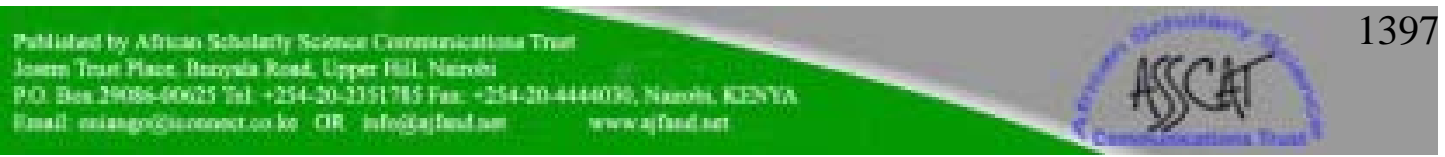


The polyphenols content of the fresh Physalis juice $(70 \mathrm{mg} / 100 \mathrm{~mL})$ was lower than that of fresh apricot juice $(150.3 \mathrm{mg} / 100 \mathrm{~mL})[6]$.

Ascorbic acid contents $(39 \mathrm{mg} / 100 \mathrm{~mL})$ were higher than those of cantaloupe juice $(37 \mathrm{mg} / 100 \mathrm{~mL})$ [22], passion fruit juice $(29.8 \mathrm{mg} / 100 \mathrm{~mL})$, lime juice $(30 \mathrm{mg} / 100 \mathrm{~mL})$ and tangerine juice $(31 \mathrm{mg} / 100 \mathrm{~mL})$, but it had lower content than that in Physalis peruviana juice $(46 \mathrm{mg} / 100 \mathrm{~mL})$ [30], lemon juice $(46 \mathrm{mg} / 100 \mathrm{~mL})$ and orange juice (50mg/100mL) [23].

Fresh Physalis juice had a higher protein amount (1.02\%) than in Physalis peruviana juice $(0.44 \%)$ [30], cantaloupe juice $(0.69 \%)$ [22], lemon juice $(0.38 \%)$, lime juice $(0.50 \%)$ and orange juice $(0.70 \%)$ [23].

\section{Storage and packaging effects on physico-chemical characteristics}

The acidity is considered one of the physico-chemical properties, which affects both organoleptic and keeping qualities of a product [1]. Decrease in $\mathrm{pH}$-values and increase in total titratable acidity during the cold storage period may be due to activity of some acid-producing bacteria such as Alicyclobacillus acidoterrestris [32]. These authors also described Alicyclobacillus species as thermo-acidophilic bacteria could survive in fruit juices at $\mathrm{pH} 3.0$.

The increase of the juice optical density is usually an index for undesirable changes in its quality and safety [1]. The darkening may be due to non-enzymatic browning reactions, as cited by Buglione and Lozano [33]; Robards et al. [34] and Gerschenson and Rojas [35].

\section{Storage and packaging effects on chemical composition}

It was clear that the hydrolysis of non-reducing sugars to reducing ones was due to the effect of acidity. This means that non-reducing sugars were inverted or hydrolyzed at a low rate under storage conditions [22, 32].

Carotenoids constitute the major coloring substances in juices. In addition, carotenoids have an effect on the juice nutritive value as they are considered as natural antioxidants and pro-vitamin A [1]. The decrease of carotenoids throughout the cold storage time could be explained by oxidation and also by Maillard reactions [36].

Polyphenolic substances are considered as dietary antioxidants, which play an important role in maintaining optimal human health. They have protective effects against heart and cancer diseases [37]. This slight decrease was inversely proportional to the non-enzymatic browning reactions [34] which increased slowly throughout the cold storage time (Fig. 6, Table 2).

Ascorbic acid is one of the most important nutrients in fruit juice, which generally reflects the nutritional and technological characteristics of the final product [1]. The 
significant_decrease of ascorbic acid during cold storage time may be due to its oxidation [35].

There was no migration of $\mathrm{Na}$ ions from glass bottles to processed juice formulas as was also found by Weinberger et al. [38]. These results proved that the glass type of these bottles not active, this mean no reaction between glass as packaging material and Physalis juice.

A slight increase in aluminum ions was observed in juice packaged in flexible laminated packs but not exceeding the safety limit of $\mathrm{Al}$ daily intake $(3.5 \mathrm{mg} / \mathrm{day})$ [39]. Intake of large_amounts of aluminum can cause many harmful effects on human health; anemia, osteomalacia (brittle or soft bones), glucose intolerance, and cardiac arrest in humans [39].

\section{CONCLUSION}

Physalis has the potential to become a commercial fruit of particular interest to the world's up-scale food industry. It could follow the strategy of kiwifruits in the 1960s that got a multimillion-dollar market. This research proved that Physalis could be an interesting candidate for processing of new functional products. The development of adequate agro-technical and storage practices could make this fruit a promising profitable new crop for African countries if it has remarkable agronomical potential that has not fully been appreciated yet. Fruit juices can be regarded as the most beneficial/attractive example of functional food, because they are naturally concentrated sources of physiologically valuable micronutrients. Fresh Physalis juice is a rich source of polyphenols and carotenoids with a high yield of juice $(64 \%)$. It contained moderate amounts of vitamin $\mathrm{C}$ and small amount of proteins. It was shown that pasteurized Physalis juice packaged in glass bottles had higher storage stability than that packaged in flexible laminated packs because it kept its nutritional and biophysical characteristics throughout storage for 6 months under refrigeration $\left(5 \pm 1^{\circ} \mathrm{C}\right.$, $85-90 \%$ RH). 
Table 1: Specifications of flexible laminated films *

\begin{tabular}{|c|c|c|c|c|}
\hline Films & $\begin{array}{l}\text { Thickness } \\
(\mathrm{mm})\end{array}$ & $\begin{array}{l}\text { Water vapor } \\
\text { permeability at } \\
38^{\circ} \mathrm{C} \\
\times 10^{12} \text { mol. } \mathrm{mm}^{-2} \text {. } \\
\mathrm{S}^{-1 \star} \cdot \mathrm{Pa}^{-1 \star 4}\end{array}$ & $\begin{array}{l}\text { Oxygen } \\
\text { transmission } \mathrm{cm}^{2} \text {. } \\
\mathrm{m}^{-2} \cdot 25.4 \text { micron }^{-1} \\
\text { thickness. } 24^{-1} \mathrm{~h} \text {. } \\
\text { atm }^{-1} \text { at } 25^{\circ} \mathrm{C}\end{array}$ & $\begin{array}{l}\text { Relative } \\
\text { humidity } \\
(\%)\end{array}$ \\
\hline Polyester & 0.015 & 0.0402 & $46.5-62$ & 90 \\
\hline Aluminum foil & 0.020 & 0.000289 & 0.00 & 95 \\
\hline $\mathrm{HDPE}^{\circ}$ & 0.025 & 0.0122 & 2667 & 97 \\
\hline \multicolumn{5}{|c|}{$\begin{array}{l}\text { Thickness of the films was measured by using an electronic digital vice caliper with } \\
\text { accuracy of } 0.01 \mathrm{~mm} \text {. } \\
\text { S = Package surface area. }\end{array}$} \\
\hline $\begin{array}{l}{ }^{*} \mathrm{~Pa}=\mathrm{Pressu} \\
{ }^{\circ} \mathrm{HDPE}=\mathrm{Hi} \\
* \text { Source: } \mathrm{Cu}\end{array}$ & $\begin{array}{l}\text { the package } \\
\text { nsity polyet } \\
\text { al. }[40] \text {. }\end{array}$ & lene. & & \\
\hline
\end{tabular}




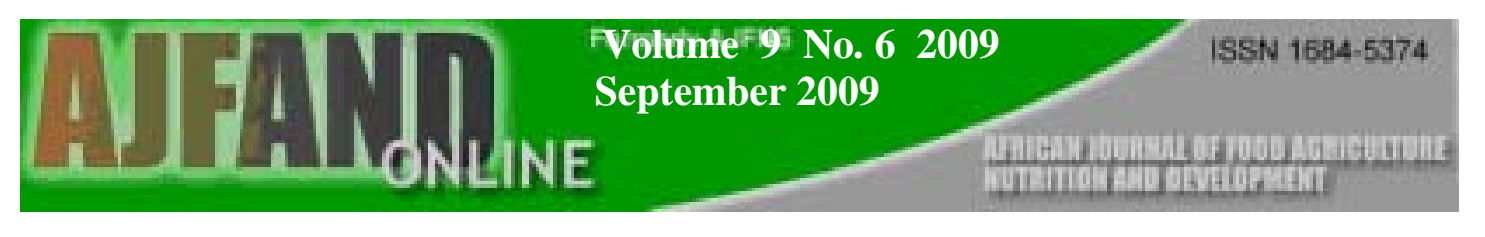

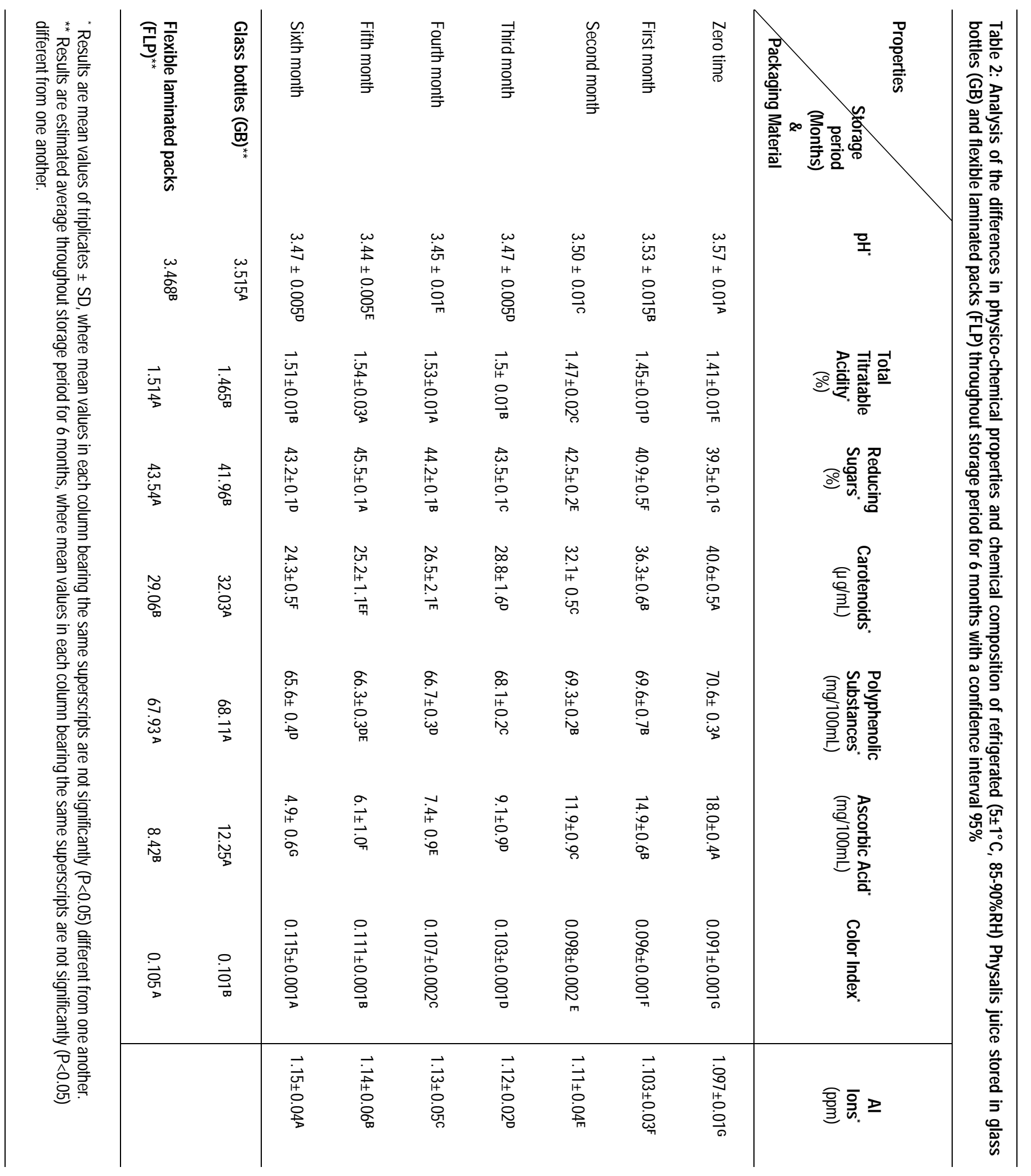




\section{REFERENCES}

1. El Sheikha AF Technological, chemical and microbiological studies on some packed foods. M.Sc. Faculty of Agriculture, Minufiya University, Egypt, 2004.

2. Dremann CG Ground Cherries, Husk Tomatoes and Tomatillos. Redwood City Seed Co. 1985; ISBN 0-933421-03-6.

3. Fouqué A Espèces fruitières d'Amérique tropicale. Fruits.1972; 17, 62-72.

4. Facciola $\mathbf{S}$ Cornucopia, a source book of edible plants. Kampong Publications, 1990; 207.

5. Coffey T The History and Folklore of North American Wild Flowers. Facts on File. 1993; ISBN 0-8160-2624-6.

6. El Sheikha AF, Zaki MS, Bakr AA, El Habashy MM and D Montet Physico-chemical properties and biochemical composition of Physalis (Physalis pubescens L.) fruits. Global Science Books Ltd., UK, Food. 2008; 2 (2), 124130.

7. U.S. Department of Agriculture, Germplasm Resources Information Network (GRIN) and Natural Resources Conservation Service Plants (NRCS) National Agriculture Laboratories. Nutrient Database for standard Reference, Release 2006. Available at http://plants.usda.gov/java/profile?symbol=PHPU7

8. Bayer Crop Science The Bayer CropScience Magazine for Modern Agriculture, 2006. Available at http://www.bayercropscience.com

9. Mannheim CH, Miltz J and A Letzter Interaction between polyethylene laminated cartons and aseptically packed citrus juices. J. Food Sci. 1987; 52 (3): 737-740.

10. Intermediate Technology Department Group "ITDG" Packaging Materials for Foods, 2003; 1-7. Available at http://www.tdg.org

11. Pankow JW Review meeting: Surface analysis of soda lime glass. NCPV and Solar Program, 2003; $1904 \quad-\quad$ 1908. Available at http://www.nrel.gov/ncpv_prm/pdfs/33586017.pdf

12. Garriguet D Rapports sur la santé: Consommation de sodium à tous les âges. 2007; 18(2): 17-33. 
13. Mubarak AE and A El-Beltagy Aluminum migration into some egyptian foodstuffs via some traditional cooking methods and storing in Aluminum pans. Minufiya J. Agri. Res. 2003; 28 (2): 469-477.

14. Barabasz W, Albińska D, Jaśkowska $\mathbf{M}$ and J Lipiec Ecotoxicology of Aluminum. Polish J. Env. Studies. 2002; 11(3): 199-203.

15. AOAC. Official Methods of Analysis, 16th Ed. Assoc. of Official Analytical Chemists, Arlington VA, 1995.

16. Dubois M, Gilles KA, Hamilton JK, Rebers PA and F Smith Colorimetric method for determination of sugar and related substances. Anal. Chem. 1956; 28: $350-356$.

17. Bajaj KL and G Kaur Spectrophotometric determination of total ascorbic acid in vegetables and fruits. Analyst. 1981; 106: 117-120.

18. Dóka $\mathbf{O}$ and D Bicanic Determination of total polyphenolic content in red wines by means of the Folin-Ciocalteu Colour-imetry Assay. Anal. Chem. 2002; 74: $2157-2161$.

19. Dagnelie $\mathbf{P}$ Statistique Théroique et Appliquée. Tome 2: Inférence Statistique à une et deux dimensions. Département De Boeck Université, De Boeck \& Larcier s.a., Bruxelles, Belgique, 1998; 373.

20. Dietary Reference Intakes "DRIs" Dietary reference intakes of nutrientsbased reference values. These are established by Nutrition Board of National Academy of Sciences. Washington, D.C., USA: National Academy Press, 2004. Available at http://www.nap.edu

21. El Sheikha AF, Zaki MS, Bakr AA, El Habashy MM and D Montet Biochemical and sensory quality of Physalis (Physalis pubescens L.) juice. Willy-Blackwell Publishing, J. Food Process. Preserv. 2009; DOI: 10.1111/j.1745-4549.2009.00382.x. (In press)

22. Moustufa BM Chemical and technological studies on some vegetables and Fruits juices. Ph.D. Faculty of Agriculture, Moshtohor, Zagazig University (Benha Branch), Egypt, 2002.

23. U.S. Department of Agriculture, National Agriculture Laboratories. Nutrient Database for Standard Reference, NDB No.11954. Washington, D.C., USA, 2006.

24. Raghava RP and $\mathbf{R}$ Nisha Carotenoid content of husk tomato under the influence of growth regulators and gamma rays. Indian J. Plant Physiol. 1990; 33: $87-89$. 
25. Cantwell M, Flores MJ and GA Trejo Developmental changes and postharvest physiology of tomatillos fruits (Physalis ixocarpa L.). Scientia Horticulturae 1992; 50: 59-70.

26. Abou-Gharbia HA and EM Abou-Tour Properties and processing of husk tomato. Minufiya J. Agric. Res. 2001; 26: 761-781.

27. USDA. National Nutrient Database for Standard Reference, NDB No.11954. The US Department of Agriculture, Washington DC., 2006. Available at http://www.nal.usda.gov/fnic/foodcomp/cgi-bin/list_nut_edit.pl

28. Joslyn MA Methods in Food Analysis, 2nd Ed., Berkeley, California, 1970; 845.

29. Carvalho LMJ, Borchetta R, Silva ÉMM, Carvalho CWP, Miranda RM and CAB Silva Effect of Enzymatic Hydrolysis on Particle Size Reduction in Lemon Juice (Citrus limon L.), cv. Tahiti. Brazilian J. Food Technol. 2006; 9: 277-282.

30. Ramadan MF and JT Moersel Impact of enzymatic treatment on chemical composition, physicochemical properties and radical scavenging activity of goldenberry (Physalis peruviana L.) juice. J. Sci. Food Agric. 2007; 87: 452460.

31. Zeid MHM Technological studies on some fruit and vegetable products. Ph.D. Faculty of Agriculture, Zagazig University, Egypt, 1996.

32. Kang DH, Dougherty RH and B Swanson Controlling Alicyclobacillus acidoterrestris in fruit juices by high pressure and high temperature. Nutr. Rep. Food Sci. Hum. Nutr. Dep. Washington State University, 2003. Available at http://www.impact.wsu.edu/research/ proposals/pdf/kangD01.pdf

33. Buglione $\mathbf{M}$ and $\mathbf{J}$ Lozano Nonenzymatic browning and chemical changes during grape juice storage. J. Food Sci. 2002; 67: 1538-1543.

34. Robards K, Prenzler PD, Glover W, Tucker G and P Swatsitang Phenolic compounds and their role in oxidative processes in fruits. Food Chem. 1999; 66: 401-436.

35. Gerschenson LN and AM Rojas Influence of system composition on ascorbic acid destruction at processing temperatures. J. Sci. Food Agric. 1997; 74: 369378.

36. Nicoli MC, Anese M and M Parpinel Influence of processing on the antioxidant properties of fruit and vegetables. Trends Food Sci. Technol. 1999; 10: 94-100. 
37. Duthie GG, Susan J, Janet A and M Kyle Plant polyphenols in cancer and heart disease: implications as nutritional antioxidants. CABI Publishing, Nutr. Res. Rev. 2000; 13: 79-106. Available at http://www.nutrition.cabweb.org

38. Weinberger MH, Miller JZ, Luft FC, Grim CE and NS Finebery Sodium sensitivity and resistance of blood pressure in human. Food Technol. 1986; 40(12): $96-98$.

39. National Research Council "NRC" Recommended Dietary Allowances, $10^{\text {th }}$ ed. National Academy Press, Washington, D.C., 1989.

40. López FF, Cabrera C, Lorenzo MC and MC López Aluminum content in foods and beverages consumed in the Spanish diet. J. Food Sci. 2000; 65 (2): $206-210$.

41. Cuq B, Gontard $\mathbf{N}$ and $\mathbf{S}$ Guilbert Edible films and coatings as active layers. In: Active food packaging; Rooney, M.L. and Csiro (Eds.) Blackie Academic and Professional An imprint of Chapman and Hall Press., London, U.K., 1995; 116-123. 